\title{
Improving Mathematics Learning Outcomes in Fractional Materials Through Audio-visual Media for Fifth Grade Students SDN Muktiharjo Kidul 04
}

\section{Tri Widya Astuti}

SD Negeri Muktiharjo Kidul 04

widwidyaastuti@gmail.com

\section{Article History}

received 3/12/2020

revised $17 / 12 / 2020$

accepted 31/12/2020

\begin{abstract}
The learning process does not only involve students directly but needs to use learning support tools. The researcher examines whether audio-visual media can improve the mathematics learning outcomes of fractions in fifth grade students of SD Negeri Muktiharjo Kidul 04. This research uses Classroom Action Research (CAR). Data analysis was carried out by calculating the achievement of student learning scores in each cycle based on KKM. The results of the study can be seen in the increase in student learning outcomes, from the results of the cycle 1 value shows an average of 60.54 with the percentage of students who complete the individual KKM 62.17\%. While in cycle 2 it shows an average of 70.27 with a complete percentage of individual KKM 83,78\%. This shows that audio-visual media can improve student learning outcomes in mathematics in class V SD Negeri Muktiharjo Kidul 04 Pedurungan District, Semarang City, Academic Year 2020/2021.
\end{abstract}

Keywords: learning outcomes, fractions, audio-visual

\begin{abstract}
Abstrak
Proses belajar tidak hanya melibatkan siswa secara langsung tetapi perlu menggunakan alat penunjang pembelajaran. Peneliti mengkaji apakah media audio visual dapat meningkatkan hasil belajar matematika materi pecahan pada siswa kelas V SD Negeri Muktiharjo Kidul 04. Jenis penelitian ini menggunakan Penelitian Tindakan Kelas (PTK). Analisis data yang dilakukan dengan cara menghitung pencapaian nilai belajar siswa tiap siklus yang berpatokan dari KKM Individual atau KKM sekolah dan KKM Nasional. Hasil penelitian dapat dilihat pada peningkatan hasil belajar siswa, dari hasil nilai siklus 1 menunjukan rata-rata 60,54 dengan persentase siswa yang tuntas KKM individu $62,17 \%$. Sedangkan pada siklus 2 menunjukan rata-rata 70,27 dengan prosentase yang tuntas $\mathrm{KKM}$ individu $83,78 \%$. Hal ini menunjukan bahwa media audio visual dapat meningkatkan hasil belajar siswa matematika pada siswa kelas V SD Negeri Muktiharjo Kidul 04 Kecamatan Pedurungan Kota Semarang Tahun Ajaran 2020/ 2021.
\end{abstract}

Kata kunci: hasil belajar, pecahan, audiovisual

Social, Humanities, and Education Studies (SHEs): Conference Series https://jurnal.uns.ac.id/shes

p-ISSN 2620-9284

e-ISSN 2620-9292

This work is licensed under a Creative Commons Attribution-ShareAlike 4.0 International License. 


\section{PENDAHULUAN}

Belajar adalah suatu proses yang kompleks yang terjadi pada diri seseorang sepanjang hidupnya. Proses itu terjadi karena adanya interaksi antara sesorang dan lingkunganya (Azhar, 2011:1). Proses itu terjadi karena adanya interaksi antara sesorang dan lingkunganya. Oleh karena itu, salah satu perubahan tingkah laku pada seseorang. Salah satu perubahan tingkah laku bahwa seseorang telah belajar adalah adanya perubahan tingkah laku pada diri seseorang itu mungkin disebabkan oleh terjadinya perubahan pada tingkat pengetahuan, keterampilan, atau sikapnya. (Arief dkk, 2012) menyatakan bahwa belajar adalah suatu proses yang kompleks yang terjadi pada semua orang dan berlangsung seumur hidup, sejak dia masih bayi hingga keliang lahat nanti. Pengertian tentang hasil belajar menurut Bloom dalam Rusmono (2017:8) bahwa hasil belajar merupakan perubahan perilaku yang meliputi tiga ranah, yaitu ranah kognitif, afektif dan psikomotor. (Oemar Hamalik, 2012) mengatakan hasil belajar itu dapat terlihat dari terjadinya perubahan dari persepsi dan perilaku, termasuk juga perbaikan perilaku. Sedangkan (Popi Radyuli, 2019) menyatakan pendapat bahwa hasil belajar merupakan perubahan tingkah laku yang terjadi pada seseorang yang dapat diamati dan diukur dalam bentuk pengetahuan, sikap dan keterampilan. Hasil belajar terbagi kedalam beberapa jenis, Benyamin Bloom (Nana Sudjana, 2013) mengkasifikasikan jenis-jenis hasil belajar menjadi tiga ranah, yaitu : ranah kognitif, afektif dan psikomotoris. Ranah kognitif berkenaan dengan hasil belajar intelektual, ranah afektif berkenaan dengan sikap dan ranah psikomotoris berkenaan dengan hasil belajar keterampilan.

Dilihat dari berkembangnya ilmu matematika yang selalu mengikuti perkembangan zaman, maka ini menjadi tugas seorang guru untuk selalu mengembangkan inovasi-inovasi dalam mengembangkan media maupun metode yang digunakan untuk pembelajaran dikelas agar siswa lebih mudah memahami dan siswa juga mengikuti adanya perkembangan zaman. Matematika tidak lepas dari kehidupan sehari-hari, namun pada kenyataannya matematika menjadi mata pelajran tidak disukai oleh siswa bahkan dihindari kususnya pada siswa SD Negeri Muktiharjo Kidul 04 Kecamatan Pedurungan Kota Semarang, hal ini mengakibatkan siswa kurang menguasai materi. Pelajaran matematika menurut kebanyakan siswa SD Negeri Muktiharjo Kidul 04 Kecamatan Pedurungan Kota Semarang adalah salah satu pelajaran yang sulit karena matematika membutuhkan ketelitian.

Mayoritas siswa mengeluhkan betapa sulitnya memahami pelajaran matematika tidak jarang pula mereka bermalas-malasan mengikuti pelajaran matematika bahkan banya dari mereka jika tes hanya mengandalkan temannya saat mengerjakan tes matematika, memang pelajaran ini memiliki tingkat kesulitan yang terkadang menjadi salah satu pelajaran yang mempunyai KKM rendah. Salah satu materi matematika adalah pecahan. Dasar materi pecahan adalah mengenal dan membandingkan pecahana siswa belum sepenuhnya mengerti tentang materi tersebut maka dari itu menjadi perhatian khusus bagi seorang guru.

Media berasal dari bahasa latin medius yang secara harfiah artinya tengah, pertama atau pengantar (Azhar, 2011:3). Media adalah manusia, materi atau kejadian yang membangun kondisi yang membuat siswa mampu memperoleh pengetahuan, keterampilan atau sikap, pengertian media dalam proses belajar cenderung diaretikan sebagai alat-alat grafis,photografis atau elektronis atau elektonis untuk menangkap, memproses dan menyusun kembali informasi visual maupun verbal. Menurut hasil PTS (Penilaian Tengah Semester) siswa SD Negeri Muktiharjo Kidul 04 Kecamatan Pedurungan Kota Semarang, pada nilai matematika diperoleh data sebanyak 28 dari 37 siswa belum mencapai Kriteria Ketuntasan Minimum (KKM) yang ditentukan sekolah pada mata pelajaran matematika yakni 60 . Hal itu berarti bahwa hanya ada 9 anak saja yang mampu mencapai (KKM) yang telah ditentukan. 
Ada beberapa faktor yang menyebabkan siswa belum mencapai Kriteria Ketuntasan Minimum (KKM) mata pelajaran matematika pecahan yakni dikarenakan guru kesulitan dalam menyampaikan materi karena pembelajaran dilaksanakan dengan cara daring. Kegiatan belajar mengajar antara guru dan siswa saat ini tidak dapat dilakukan tatap muka secara langsung. Pembelajaran secara daring ini dilakukan karena hampir seluruh bagian negara di dunia saat ini sedang dilanda wabah COVID-19 termasuk negara kita Indonesia. Penularan wabah tersebut sangat mudah menyerang siapa saja. Sehingga selama belum ditemukan vaksin yang dapat mencegah penularan wabah tersebut, pemerintah masih membatasi kegiatan belajar mengajar di sekolah. Selain itu pembelajaran masih terpusat pada guru dimana siswa hanya menerima materi lewat HP, guru hanya mengirimkan materi lewat foto tanpa melihat apa yang guru sampaikan, metode yang digunakan oleh guru kurang tepat ditambah guru hanya terpusat pada buku yang digunakan untuk mengajar tidak hanya guru siswa juga kutrang trampil dalam mengenal dan membandingkan pecahan biasa.

KKM menjadi acuan bersama antara pendidik, peserta didik, dan orang tua pendidik. Beberapa penyebab nilai siswa belum mencapai Kriteria Ketuntasan Minimum (KKM) harus segera diatasi agar pembelajaran dapat dilaksanakan dengan tuntas sesuai alokasi waktu yang tersedia. Untuk itu peneliti mencoba alternatif pemecahan diantaranya yang dirasa paling cocok dengan menggunakan media audio visual, hal itu dapat diketahui dari hasil belajar siswa dari siklus 1 ke siklus berikutnya, dari siklus 1 hasil belajar meningkat dari nilai pra siklus, yang semula 24,3\% pada siklus 1 meningkat menjadi $62,2 \%$. Sedang rata-rata siklus 2 telah mencapai KKM dengan rata-rata 70,2 .

Rumusan masalah dalam penelitian adalah, "Apakah media audio visual dapat meningkatkan hasil belajar matematika pecahan dengan media audio visual pada siswa kelas V di SD Negeri Muktiharjo Kidul 04 Kecamatan Pedurungan Kota Semarang Tahun Pelajaran 2020/ 2021?"

Tujuan penelitian ini adalah untuk mengetahui peningkatan hasil belajar matematika materi pecahan dengan media audio visual pada siswa kelas $V$ di SD Negeri Muktiharjo Kidul 04 Kecamatan Pedurungan Kota Semarang Tahun Pelajaran 2020/ 2021.

\section{METODE}

Pada penelitian ini menggunakan desain penelitian tindakan kelas. Penelitian tindakan kelas merupakan suatu pencermatan terhadap kegiatan belajar berupa sebuah tindakan (Suharsimi, 2011:3), yang sengaja diumculkan dan terjadi dalam sebuah kelas secara bersama. Penelitian tindakan kelas itu sendiri mengharuskan guru untuk selalu berusaha melakukan tindakan pembaharuan (inovasi) dalam proses belajar mengajar. Adapun model PTK yang diterapkan adalah model Kemmis\&McTaggart. Model ini merupakan pengembangan dari konsep dasar yang dikemukakan oleh Kurt. D Lewin. Dalam model ini, PTK dilaksanakan melalui 4 tahap yaitu perencanaan, pelaksanaan tindakan, observasi, dan refleksi dimana pelaksanaannya berkelanjutan ke siklus-siklus berikutnya.

Penelitian dengan bantuan media audio-visual ini dilaksanakan dalam dua siklus dengan masing-masing siklus terdiri dari satu pertemuan. Subjek penelitian adalah siswa kelas V SD Negeri Muktiharjo Kidul 04 yang berjumlah 37 siswa, yang terdiri dari 21 siswa perempuan dan 16 siswa laki - laki, dengan mata pelajaran matematika materi pecahan. Penelitian Tindakan Kelas ini dilaksanakan di SD Negeri Muktiharo Kidul 04 Kota Semarang pada minggu ke 4 bulan September dan minggu ke 3 bulan Oktober 2020. Teknik pengumpulan data pada penelitian ini adalah kuantitatif. Data kuantitatif dalam penelitian ini diperoleh dari hasil belajar siswa. 


\section{HASIL DAN PEMBAHASAN}

Penelitian tindakan kelas yang direncanakan menggunakan 2 siklus, dengan standar kompetensi memahami pecahan sederhana dalam pemecahan masalah. Siklus pertama dan kedua menguraikan sub pokok bahasan yang berbeda yaitu siklus I sub pokok bahasan "Mengenal Pecahan". Siklus 2 sub pokok bahasan "Mengenal dan Membandingkan Pecahan". Waktu pelaksanaan 2x35 menit (2 jam pelajaran) dalam 1 kali pertemuan. Dalam penelitian ini setiap pembelajaran di gunakan lembar soal dan lembar observasi untuk mengukur sejauh mana prestasi belajar siswa dan target KKM yang dicapai siswa setelah mengikuti pembelajaran matematika dengan menerapkan media audio visual.

Siklus 1 merupakan proses pembelajaran dengan materi pecahan yang dilaksanakan hari Senin tanggal 21 September 2020 dengan alokasi waktu dua kali pertemuan yaitu 2 jam pelajaran $(2 \times 35$ menit). Proses pembelajaran pada siklus 1 berupa kegiatan untuk mempertimbangkan dan memilih upaya-upaya yang dapat dilakukan untuk mencari pemecahan masalah yang didapat dari refleksi pembelajaran prasiklus. Pertimbangan dan pemilihan pemecahan masalah tersebut meliputi perencanaan. Pada tahap perencanaan dilakukan persiapan dengan menentukan media pembelajaran yang akan digunakan sesuai dengan materi pokok tujuan penelitian. Kemudian menyusun rencana pembelajaran yang sesuai dengan materi. Rencana pembelajaran ini digunakan sebagai program dalam melaksanakan proses pembelajaran agar tujuan pembelajaran dapat tercapai. Guru merancang pembelajaran dengan menggunakan media pembelajaran audio visual. Hal ini dilakukan guru agar dalam perencanaan pembelajaran lebih mudah dan menyenangkan bagi siswa sehingga tujuan yang ingin dicapai dalam pembelajaran tersebut dapat tercapai. Selain itu, guru menyiapkan lembar observasi siswa dan lembar observasi guru untuk dijadikan pedoman penilaian serta menyiapkan soal-soal dalam lembar kerja siswa untuk mengetahui hasil belajar siswa. Pada tahap tindakan, guru melaksanakan tindakan pembelajaran dari rencana yang telah disusun yaitu guru melaksanaan pembelajaran selama $2 x$ pertemuan (2x35menit). Pada tahap pengamatan, guru melakukan pengamatan terhadap kegiatan siswa dalam kegiatan pembelajaran. Melalui lembar observasi, guru mengamati tingkah laku siswa selama kegiatan pembelajaran berlangsung. Kepala sekolah sebagai observer mengamati proses pemberian tindakan yang dilakukan. Setelah kegiatan berakhir, lembar kerja siswa diberi skor penialain dengan skala penilaian yang telah disiapkan.

Tahap pembelajaran siklus 1 merupakan proses pembelajaran materi penjumlahan pecahan dengan penyebut yang berbeda yang telah menggunakan media pembelajaran audio visual yang belum sepenuhnya terlaksana sesuai rencana. $\mathrm{Hal}$ ini disebabkan karena guru belum berhasil memfokuskan perhatian anak sepenuhnya pada media pembelajaran ini. Dari data diatas dapat diketahui bahwa hasil pembelajaran siklus 1 materi penjumlahan pecahan dengan penyebut yang berbeda masih kurang dmatematikahami oleh siswa. Nilai ketuntasan klasikal yaitu $62,20 \%$, Siswa yang mencapai KKM sebanyak 23 siswa, dan yang belum tuntas sebanyak 14 siswa mencapai rata-rata kelas 60,54. Meski rata-rata kelas sudah melampaui KKM namun pada siklus 1 masih belum memenuhi indikator yang ditentukan yakni nilai ketuntasan secara klasikal masih kurang dari $80 \%$.

Siklus 2 merupakan proses pembelajaran dengan materi pecahan dengan mengubah bentuk pecahan dilakukan dengan media pembelajaran audio visual yang dilaksanakan hari Senin tanggal 19 Oktober 2020 dengan alokasi waktu 2x pertemuan yaitu 2 jam pelajaran ( 2 x 35 menit). Proses pembelajaran pada siklus 2 berupa kegiatan yang dapat dilakukan untuk mencari pemecahan masalah yang didapat dari refleksi pembelajaran pada siklus I. Perencanaan pada tahap pembelajaran sklus 2 ini hampir sama pada tahap pembelajaran siklus 1 . Kemudian menyiapkan media audio visual untuk menarik perhatian siswa. Selain itu, guru menyiapkan lembar observasi 
siswa dan lembar observasi guru untuk dijadikan pedoman penilaian. Guru menyiapkan soal-soal dalam lembar kerja siswa untuk mengetahui hasil belajar siswa. Pada tahap tindakan, guru melaksanakan tindakan pembelajaran dari rencana yang telah disusun yaitu guru melaksanaan pembelajaran selama $2 \times$ pertemuan $(2 \times 35$ menit). Pada tahap pengamatan guru melakukan pengamatan terhadap kegiatan siswa melalui lembar observasi. Setelah kegiatan berakhir lembar kerja siswa diberi skor penialain dengan skala penilaian yang telah disiapkan.

Tabel 1. Perbandingan Hasil Belajar Tiap Siklus

\begin{tabular}{ccccccccc}
\hline & & \multicolumn{2}{c}{ Prasiklus } & \multicolumn{2}{c}{ Siklus I } & \multicolumn{2}{c}{ Siklus 2 } & Ket. \\
\cline { 2 - 7 } No & Nilai & $\begin{array}{c}\text { Jumlah } \\
\text { siswa }\end{array}$ & Persentase & $\begin{array}{c}\text { Jumlah } \\
\text { siswa }\end{array}$ & Persentase & $\begin{array}{c}\text { Jumlah } \\
\text { siswa }\end{array}$ & Persentase & \\
\hline 1. & 560 & 28 & $75,67 \%$ & 14 & $37,83 \%$ & 6 & $16,22 \%$ & $\begin{array}{c}\text { Belum } \\
\text { Tuntas }\end{array}$ \\
2. & $\geq 60$ & 9 & $24,33 \%$ & 23 & $62,17 \%$ & 31 & $83,78 \%$ & Tuntas \\
$\begin{array}{c}\text { Jumlah } \\
\begin{array}{c}\text { Rerata } \\
\text { kelas }\end{array}\end{array}$ & 37 & 100 & 37 & 100 & 37 & 100 & \\
\hline
\end{tabular}

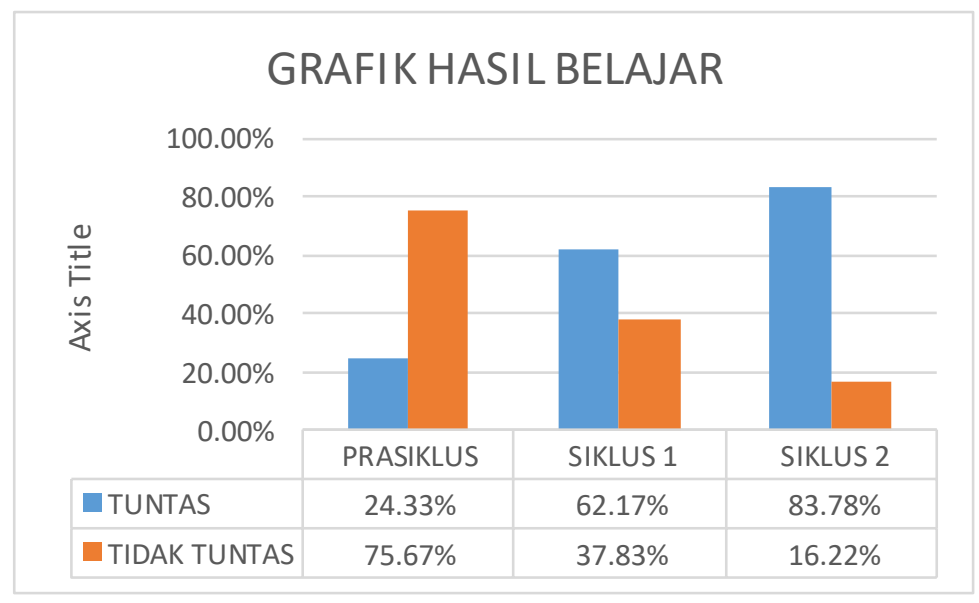

Gambar 1. Hasil Belajar Siswa selama dua siklus

Aktivitas siswa pada prasiklus masih tergolong cukup rendah. Sebagian siswa belum aktif di dalam pembelajaran dan interaksi dengan guru. Hal ini disebabkan kurang atau tidak diberi motivasi dengan baik. Oleh karena itu pada setiap proses pembelajaran berlangsung siswa harus selalu diberi bimbingan dan motivasi agar tumbuh rasa percara diri yang yang akhirnya bersemangat untuk melaksanakan pembelajaran pada materi ini. Adapun siswa masih belum sepenuhnya memahami media audio visual ini disebabkan karena belum terbiasa, maka sangat perlu siswa diberikan penjelasan cara dan motivasi. Pada kegiatan pembelajaran prasiklus, siswa masih banyak yang mengalami kesulitan dalam mengerjakan soal pada lembar kerja siswa. Dari soal-soal yang diberikan, siswa melakukan kesalahan hampir merata. Pada kegiatan pembelajaran siklus 1, siswa mulai memahami materi pecahan yang benar. Rasa percaya diri telah terbuka dilihat dari mereka mengerjakan soal secara mandiri, maka sangat baik apabila diberi kesempatan seluas-luasnya. Siswa 
mengerjakan semua soal dengan tenang, tertib karena mengharapkan nilai yang terbaik. Berarti rasa tanggung jawab dan percaya diri sudah dimiliki dan disadari oleh masing-masing siswa. Siklus 1 menunjukkan bahwa sebagian besar siswa sudah paham dengan penjelasan guru tentang materi pelajaran.

Pada siklus 2 siswa mampu mengikuti pembelajaran dengan baik serta senang belajar. Penggunaan media audio visual dalam proses belajar mengajar dapat merangsang keterlibatan intelektual dan emosional siswa sehingga siswa mengalami peningkatan hasil belajar dibandingkan dengan hasil tes-tes sebelumnya. Siswa mengerjakan tes akhir dengan semangat. Persentase ketuntasan siswa mencapai $83,78 \%$ dari jumlah total 37 siswa. Dengan demikian pada siklus 2 dmatematikandang sudah cukup, karena prestasi hasil belajar siswa saat mengerjakan tes telah mencapai nilai ketuntasan diatas tolok ukur keberhasilan yaitu di atas atau lebih dari $80 \%$.

Berdasarkan data yang diperoleh pada tahap pembelajaran siklus 2, diketahui bahwa persentase nilai ketuntasan siswa secara klasikal dalam penguasaan materi pecahan mengalami peningkatan dari yaitu mencapai $83,78 \%$ yang berarti telah memenuhi indikator yang ditetapkan yaitu lebih dari $80 \%$. Hasil belajar siswa yang mencapai KKM ada 31 siswa dan yang belum mencapai KKM ada 6 siswa saja dengan presentase $16.22 \%$. Hal ini berarti hasil belajar siswa pada materi pecahan telah berhasil dengan media pembelajaran audio visual telah berhasil sehingga penelitian berhenti pada siklus 2 .

\section{SIMPULAN}

Berdasarkan rumusan masalah, hasil analisis data dan pembahasan dapat disimpulkan bahwa pelaksanaan pembelajaran dengan menggunakan media pembelajaran audio visual adalah hasil belajar siswa kelas V SD Negeri Muktiharjo 04 Semarang pada pembelajaran materi pecahan mengalami peningkatan. Pada tahap prasiklus tes hasil belajar siswa pada pembelajaran matematika materi pecahan menunjukkan bahwa ketuntasan belajar siswa secara klasikal hanya mencapai 24,30 $\%$ dengan rata-rata kelas 40,54. Pada siklus 1 tes hasil belajar siswa pada pembelajaran matematika materi pecahan menunjukkan bahwa ketuntasan belajar siswa secara klasikal naik menjadi $62,27 \%$ dengan rata-rata kelas 60,54 . Pada siklus 2 tes hasil belajar siswa pada pembelajaran matematika materi pecahan bisa menunjukkan bahwa ketuntasan belajar siswa secara klasikal naik menjadi 83,78 \% dengan rata-rata kelas 70,27.

\section{DAFTAR PUSTAKA}

Arief S. Sadiman, dkk. (2011). Media Pendidikan, Pengertian, Pengembangan, dan Pemanfaatannya. Jakarta : PT. Raja Grafindo Persada.

Arikunto, Suharsimi, dkk. (2011). Penelitian Tindakan Kelas. Jakarta: PT Bumi Aksara.

Azhar Arsyad. (2011). Media Pembelajaran. Jakarta : PT Raja Grafindo Persada.

Hamalik, Oemar. (2012). Pendekatan Baru Strategi Belajar Mengajar Berdasarkan CBSA. Bandung : Sinar Baru Algesindo

Nana Sudjana. (2013). Dasar-Dasar Proses Belajar Mengajar. Bandung: Sinar Baru Algesindo

Popi Radyuli, Rini Sefriani, Nurul Qomariah. (2019). Pembelajaran Inquiry Menggunakan Google Form Terhadap Hasil Belajar Simulasi dan Komunikasi Digital. Edukatif Jurnal IImu Pendidikan, 1(2), 56-96.

Rusmono. (2017). Strategi Pembelajaran Dengan Problem Based Learning Itu Perlu (Edisi Kedua). Bogor: Ghalia Indonesia.

Sadiman Arief S, dkk. (2012). Media Pendidikan. Jakarta : Raja Grafindo Persada. 